\title{
Development of a sustainable livelihood security model for storm- surge hazard in the coastal areas of Bangladesh
}

\author{
Mahmuda Mutahara ${ }^{1,2,6} \cdot$ Anisul Haque ${ }^{2}$ M. Shah Alam Khan ${ }^{2}$. \\ Jeroen F. Warner ${ }^{3} \cdot$ Philippus Wester ${ }^{4,5}$
}

Published online: 18 March 2016

(c) The Author(s) 2016. This article is published with open access at Springerlink.com

\begin{abstract}
Coastal communities in Bangladesh are at great risk due to frequent cyclones and cyclone induced stormsurges, which damages inland and marine resource systems. In the present research, seven marginal livelihood groups including Farmers, Fisherman, Fry (shrimp) collectors, Salt farmers, Dry fishers, Forest resource extractors, and Daily wage labourers are identified to be extremely affected by storm- surges in the coastal area of Bangladesh. A livelihood security model was developed to investigate the security status of the coastal livelihood system in a participatory approach. In the model, livelihood security consists of five components: (1) Food, (2) Income, (3) Life \& health, (4) House \& properties, and (5) Water security. Analytical hierarchy process was followed to assess the livelihood security indicators based on respondents' security options. The model was verified through direct field observation and expert judgment. The Livelihood Security Model yields a Livelihood Security Index which can be used for assessing
\end{abstract}

Mahmuda Mutahara

mahmuda.ruma@gmail.com; mahmuda.mutahara@wur.nl

1 Social Science Group (SSG), Wageningen University, Wageningen, The Netherlands

2 Institute of Water and Flood Management (IWFM), Bangladesh University of Engineering and Technology (BUET), Dhaka, Bangladesh

3 Disaster Studies, Wageningen University, Wageningen, The Netherlands

4 Water Resources Management, International Centre for Integrated Mountain Development, Kathmandu, Nepal

5 Water Governance, Water Resources Management Group, Wageningen University, Wageningen, The Netherlands

6 Education and Competency Studies (ECS) Group, Wageningen University, Wageningen, The Netherlands and comparing the household security level (in \%) of different livelihood groups in the storm-surge prone coastal areas. The model was applied with data from two major coastal areas (Cox's Bazar and Satkhira) of Bangladesh and is applicable to other coastal areas having similar settings.

Keywords Storm-surge $\cdot$ Hazard - Community $\cdot$ Coastal zone $\cdot$ Livelihood security $\cdot$ Multi- criteria analysis . Bangladesh

\section{List of symbols}

$I_{p} \quad$ Present value of individual indicator

$\mathrm{I}_{\mathrm{s}} \quad$ Standard value of individual indicator

$I_{d} \quad$ Percentage of unit difference between present value of indicator and standard value of indicator

i Livelihood Indicator

j Security aspects/options

$\mathrm{n}$ Number of indicators responds to an individual security options

$\mathrm{N}$ Number of security aspects present in the final index

SI Livelihood security index that calculates the security level for household in \%

$\mathrm{X}$ Positive value of $\mathrm{I}_{\mathrm{d}} /$ security score for individual indicator

$\mathrm{Y}$ Negative value of $\mathrm{I}_{\mathrm{d}} /$ Insecurity score for individual indicator

$\mathrm{X}_{\mathrm{ij}}$ Positive score/security score of ith indicators under jth aspect

$\mathrm{M}_{\mathrm{j}} \quad$ Maximum score of total indicators under jth aspect

$\mathrm{SI}_{\mathrm{j}} \quad$ Security index under $\mathrm{jth}$ individual aspect

$\mathrm{SI}_{1} \quad$ Food security

$\mathrm{SI}_{2}$ Income security

$\mathrm{SI}_{3} \quad$ Health and personal security

$\mathrm{SI}_{4} \quad$ Security of house and properties

$\mathrm{SI}_{5} \quad$ Water security 


\section{Introduction}

The Bay of Bengal is prone to tropical cyclones and accounts for $5.5 \%$ of the global total cyclonic storms (Ali 1996, 1999). From 1797 to 1998, 67 major cyclone induced storms and tidal surges (Brammer 1999; Chowdhury 2002) struck the Bangladesh delta, including the highly destructive cyclones Sidar and Aila in November 2007 and May 2009 respectively (BUET 2008; Hasegawa 2008; Mutahara 2009).

The coastal resource system of Bangladesh consists of rich terrestrial and marine ecosystems, including vast mangroves (the Sundarbans) and a large number of estuaries (Islam 2004). The livelihood pattern of the coastal communities mainly depends on the availability of these resources in terms of ownership and access (Soussan and Datta 2002). In many countries, higher population density on the coast is accompanied by intensification of human activity, developments, and changes in land-use (Levy and Hall 2005). However, in Bangladesh, overcrowding in the mainland drives the poor and landless people to live in the coast where they are exposed to frequent cyclone and storm surges (IPCC 1996; Rahman 2004). Staying alive, and livelihood security is central to the welfare of the coastal communities (Mutahara et al. 2013); and increasingly perilous as the frequency of cyclonic storm-surges are increasing due to climate change (Emanuel et al. 2008).

This article represents a conceptual model to assess the household livelihood security against cyclone and storm-surge risks in the coastal area. The livelihood security model is generally a combination of three intervention strategies at the household level such as livelihood promotion (development oriented programming), livelihood protection (rehabilitation/ mitigation oriented programming) and livelihood provisioning (relief-oriented programming) (Frankenberger and McCaston, 1998). Based on these strategies, the model assesses the livelihood protection and provision required for the coastal community vulnerable to storm surge. The livelihood security model developed here draws on the Socio-economic Vulnerability Index (SeVI) (Ahsan and Warner 2014), which measures socio-economic vulnerability to climate change disasters along the Bangladesh coast. It intends to bridge the gap between the necessities and priorities of communities at the micro level and policy variables at the meso level.

The current study focuses on the marginal livelihood groups and measures their household livelihood security to determine a comparative statistics of security level for different livelihood groups as well as different coastal settings. Livelihood security is an integrated concept, comprised of the capabilities, assets and activities required for a means of living. A livelihood system is sustainable if it can cope with and recover from stress and shocks (Charvet et al. 2014), maintain or enhance its capabilities and assets, and provide sustainable livelihood opportunities for the next generation (Chambers and Conway 1992). The Sustainable Livelihood Security Model defines dynamic livelihood systems, identifying the security options, synthesizing the security indicators (Goodin and Wright 1998; Saaty 1980, 1988) with participatory approaches and finally, integrating a Livelihood Security Index to quantify household livelihood security.

\section{Coastal livelihoods in the Bangladesh delta}

According to Edward and Frank (2001), a livelihood comprises "the assets (natural, physical, human, financial and social capital/resources), the activities, and the access to these (mediated by institutions and social relations) that together determine the living gained by the individual or household". Livelihoods have differed as to their environmental, social, and institutional settings and often vary in terms of resource base, production relations, and marketing (PDO-ICZM 2002). In the coastal area, some people work independently (e.g. fry collector), some work as lessees or share croppers (e.g. salt farmers, shrimp farmers) and some are contracted labourers (Ahmad 2003; Rahman 2004). Some people make a living from the exploitation of natural resources (e.g. salt farmers, fry collectors, fisherman, honey collectors) and some live on skill-based human resources (e.g. boat-building carpentry, net making). We conducted this study on livelihood groups in the storm-surge affected areas in Bangladesh (PDO-ICZMP 2003). The storm-surge risk is the most severe for the marginal people who are fully dependent on the natural resources of the coast (Khalequzzaman 1988). The first step of the study entailed an analysis of existing information sources to determine the livelihood classes in the coastal areas of Bangladesh.

Coastal livelihood groups listed in Table 1 have been defined considering the following contexts:

- Income time frame of coastal livelihood groups is influenced by the occurrences of cyclone induced storm-surges (generally occurring during the pre- and the post-monsoon) (Ganter 1996).

- Cyclones and tidal surges cause loss of life and damage resources in various ways: For examples, agro-products, shrimp, and salt are washed away; fisherman cannot go out fishing; people cannot go outside for food, water, fuel, and daily needs; houses and sanitation systems are badly damaged.

\section{Approach and methodology}

Two case studies were selected for the current research. Coastal districts Cox's Bazar and Satkhira (Fig. 1) are located near the southeast and south-west boundaries of the 
Table 1 Marginal livelihood groups in Bangladesh coast

\begin{tabular}{|c|c|c|}
\hline Livelihood groups & Resources and opportunities & Income time frame \\
\hline Farmer & $\begin{array}{l}\text { Agricultural products i.e. paddy, vegetables, } \\
\text { and shrimp farms }\end{array}$ & Round the year \\
\hline Fisherman & $\begin{array}{l}\text { Estuary, open sea (The Bay of Bengal), } \\
\text { Rivers and Khals especially in the } \\
\text { Sundarbans area }\end{array}$ & Round the year \\
\hline Dry fisher ${ }^{\mathrm{a}}$ & Fish captured from the sea and other sources & Seasonal (6-months in a year) \\
\hline Salt farmer & Salt cultivation in the coastal area & Seasonal (6 months in a year) \\
\hline Fry collector & $\begin{array}{l}\text { Estuary, coast line of the Bay of Bengal, } \\
\text { Rivers and Khals, especially in the } \\
\text { Sundarbans area }\end{array}$ & Round the year \\
\hline Forest extractor (Bawals, mouals) ${ }^{\mathrm{b}}$ & $\begin{array}{l}\text { The Sundarbans (the largest mangrove forest } \\
\text { in the world) }\end{array}$ & $8-10$ months in a year \\
\hline Wage Labourer & $\begin{array}{l}\text { Agriculture, culture fishery (Shrimp Ghers), } \\
\text { fish processing factories and others }\end{array}$ & Round the year \\
\hline
\end{tabular}

${ }^{a}$ Dry Fisher means people who are only involved in fish drying and selling

b Bawals refers to wood, leaves, and shell collectors; Mouals means honey and wax collectors

(PDO-ICZMP 2004; Mutahara 2009; Mutahara et al. 2013)

Bangladesh delta in the high and medium cyclone and surge risk zones (PDO-ICZMP 2003).

Livelihoods in rural Bangladesh are diversifying (Toufique and Turton 2002). Our field investigation confirms that this observation applies even more to the coastal zone in Bangladesh. Livelihood patterns in Cox's Bazar and Satkhira are different due to different biophysical settings as well as available resource systems. Cox's Bazar is located along the long open seashore and Satkhira is bounded by the largest mangrove forest in the world: the Sundarbans. The main methodological concept has been developed in a participatory approach (Huq 2001; Evan et al. 2005) followed in environmental and social research. It includes designing an indicator framework having a set of indicators for the security criteria in the livelihood resources system (Fig. 2) in the context of a developing country.

Indicators were identified under natural capital/resources, human capital/resources, social capital/resources, physical capital/resources and financial capital/resources representing the main livelihood sub-systems in the coastal area. In each study sites, a two-step participatory approach was adopted. First, Focus Stakeholder Meetings (FSMs) (Mutahara 2009) were conducted to understand the local livelihood systems as well as to develop an indicator framework. Second, indicators' responses towards specific livelihood security options were evaluated with a participatory approach using Analytical Hierarchy Process (AHP) (Saaty 1980, 1988); a multi-criteria decision making (MCDM) method commonly used in studies for risk-based environmental decision-making process (Tesfamariam and Sadiq 2006; Sadiq and Tesfamariam 2009). AHP provides a rational choice of different alternatives (the initially developed indicators) by identifying relevant criteria and evaluating a weighted score for each alternative that reflects its strength of preference (Goodwin and Wright 1998).

We used AHP to integrate subjective and personal preferences of indicators in performing the base analyses to develop the model. It is a systematic, explicit, and robust mechanism for eliciting and quantifying the subject judgment. Indicators were chosen from the initial indicator list under different livelihood-security aspects/options (Mutahara 2009): (1) Food security, (2) Income security, (3) Health and personal security, (4) Security of house and properties, and (5) Water security. Top-ranking indicators have been defined as the potential indicators to explore individual option of security which are the main inputs to the model.

In the second step, FSMs and individual household interviews were conducted to evaluate indicators for livelihood groups. Standard threshold values for the indicators were calculated from national and regional-level secondary information sources, including the Bangladesh Bureau of Statistics (BBS), the Local Government Engineering Department (LGED), Bangladesh; PDO-Integrated Coastal Zone Management Office; the Asian Development Bank; and the Center for Environmental and Geographical Information Services (CEGIS), Bangladesh. The model was verified through direct field observation and expert judgment. We also checked the validity of the application of the model to both field sites. For that, 10 households with approximately the same income level which had survived well through several storm-surges within the last two decades were selected randomly. We used an average value of livelihood indicators for those households to calculate the expected/standard household security level, to validate the livelihood security model developed here. 


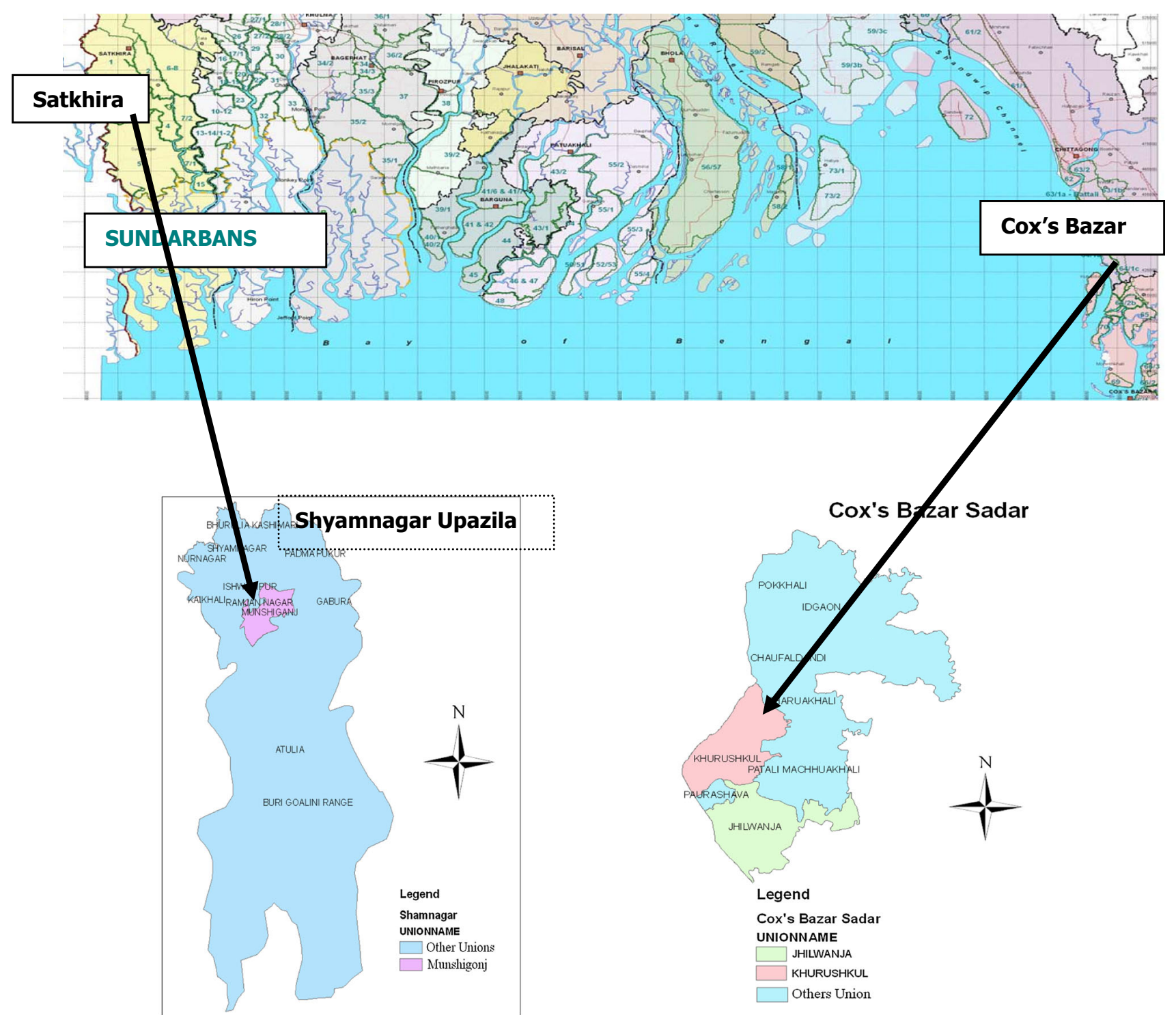

Fig. 1 Study area map showing the study sites in the coastal zone of Bangladesh

\section{Model development for livelihood security}

\subsection{The conceptual model}

The conceptual framework focuses on integrated assessment of the livelihood security required for livelihood protection and provision. The model broadly covers livelihood security against storm-surge risks and relates to the characteristics of the coastal livelihood systems in the Bangladesh Delta (Mutahara 2009; Mutahara et al. 2013).

Figure 3 conceptually shows the model for coastal livelihood security with its three major elements: (a) contexts, (b) livelihood system and strategy, and (c) livelihood security dimensions/outcomes. Contextual factors situate in the household and community. The model is constructed to identify the level of (in) security of the coastal people/household exposed to storm-surge hazards. In that sense storm-surge and its destructive actions is defined as the key contextual factor affecting the livelihoods.

The coastal livelihoods and their stakeholders are the basic elements of the model (CEGIS 2007). It has been defined as the element of vulnerability in that study field (Chadwick 2003; CEGIS 2007). In the model, the affected party i.e. the coastal livelihood groups have been introduced including their household activities, resources, and strategies. Here, the aim of analyzing livelihood system and strategy was to understand the typical accessibility of human, social, economic, and natural capital in households and the nature of production, income, and exchange activities. Livelihood security indicators are the analytical inputs to the model, which were defined for the household 


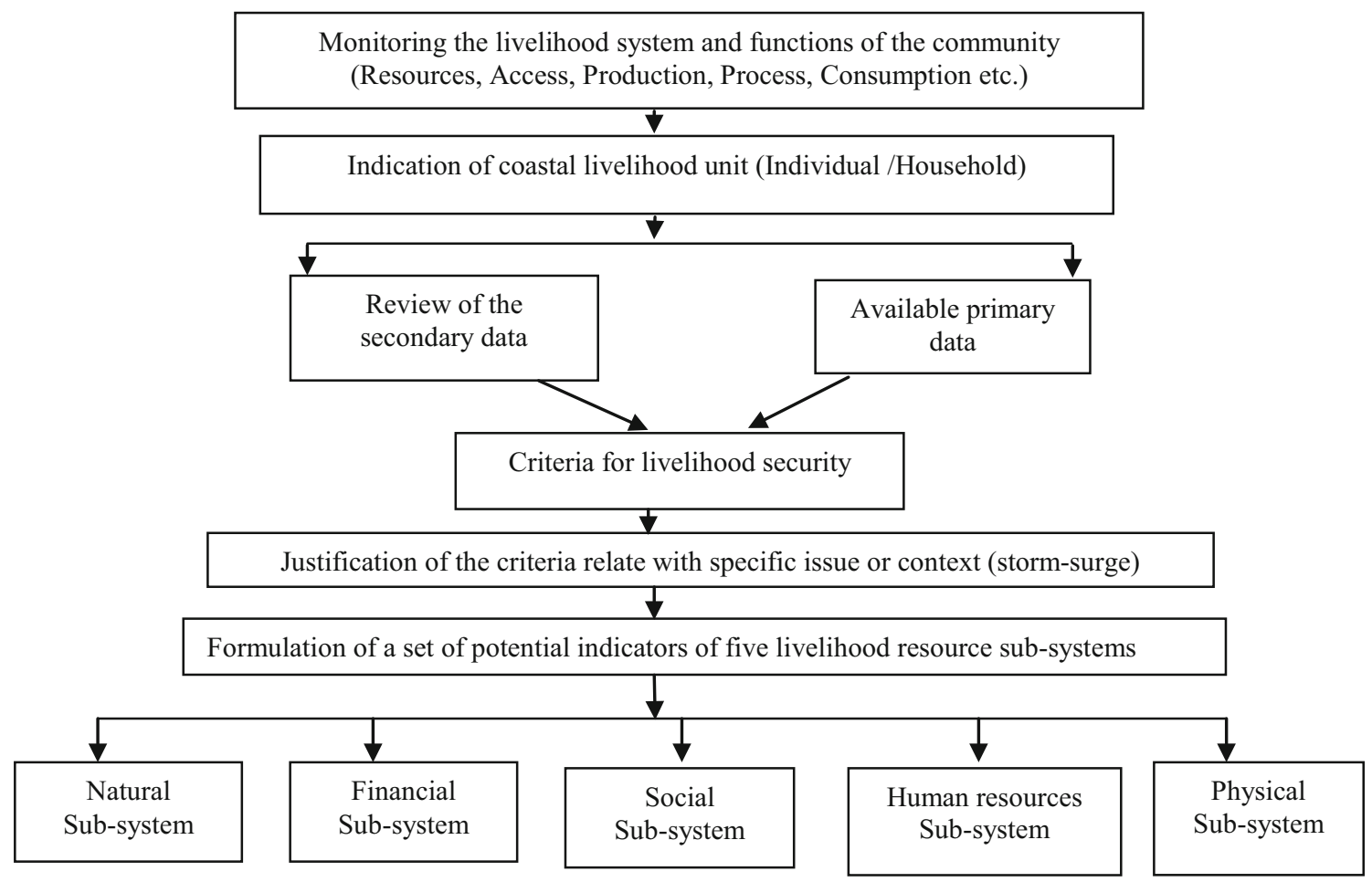

Fig. 2 Schematic representation of indicator frame work development process

unit in the livelihood system of a coastal community. The identified indicators are listed in Table 2.

In the model, the standard threshold value of a livelihood indicator is used to analyze the security level. The threshold level could be a constant value or could vary by month, season, or year (Fleig et al. 2006). Table 2 shows the security standard (threshold value of livelihood security indicators) has been shown according to national/regional statistics (yearly) in Bangladesh (BBS 2001, 2011; NWRD 2010). The security level was calculated for individual livelihood groups. Analytically, the model produces a Livelihood Security Index (SI) which is a combination of the parameters defined in Table 3.

\subsection{Designing a livelihood security index from the conceptual model}

The developed model is a scientific tool for assessing household security for any livelihood group in the coastal areas exposed to storm-surge hazard. The following steps were followed in developing the Security Index.

Step 1 Two types of values for each selected indicator have been calculated through analyzing secondary data, FGDs and mostly household interviews in the coastal area. Here, change between the present value and standard value was calculated for each individual indicator which is shown as percentage of unit difference. Change in Individual indicator was calculated under an individual security aspect by the following equation:

$\left|\mathbf{I}_{\mathbf{d}}\right|=\left\{\left(\mathbf{I}_{\mathbf{p}}-\mathbf{I}_{\mathbf{s}}\right) /\left(\mathbf{I}_{\mathbf{p}}+\mathbf{I}_{\mathbf{s}}\right)\right\} \times \mathbf{1 0 0}$

Here, $I_{p}$ is the Present value of individual indicator, $I_{s}$ is the Standard value of individual indicator, $I_{d}$ is the Percentage of unit difference between the present value of indicator and the standard value of individual indicator.

Step 2 A value exchange scale is defined in this step to identify the security score from the result of Step 1 because the value of $I_{d}$ may represent alternative directions, i.e. either positive $(+)$ or negative $(-)$. Here, the positive direction shows security and negative direction shows insecurity.

In this model development process, we used only positive scores because conceptually this model is able to measure security at the household level. Insecurity level for the same household can be identified directly and easily using the model upshot.

Step 3 Security of household (in percentage) for individual livelihood security aspects/options which is at risk of storm-surges in the coast has been measured by the index defined below. The security level for household in individual security aspects/option (j) can be calculated by using security scores of indicators $(i=1$, 


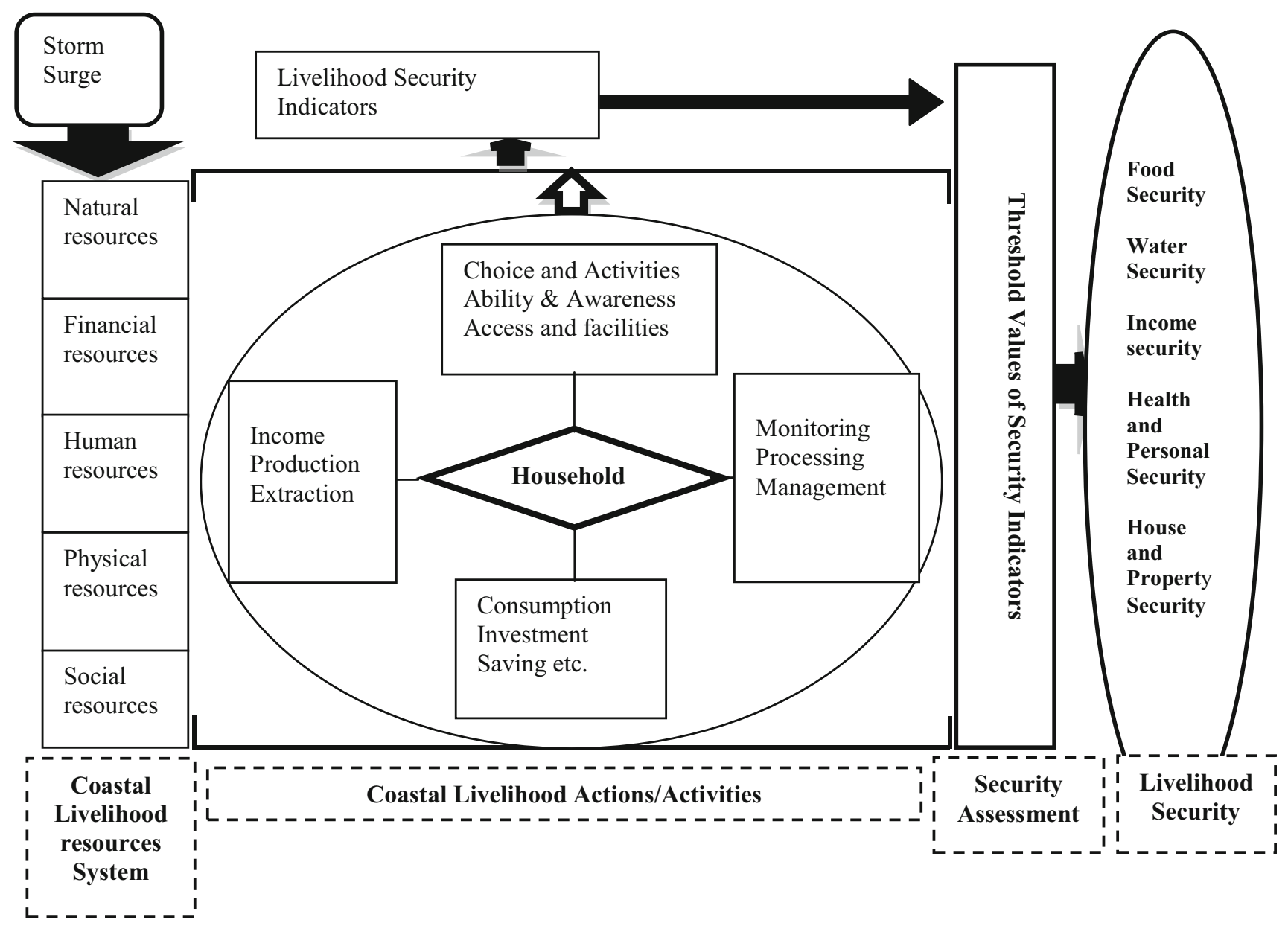

Fig. 3 Components of the model of livelihood security against storm-surge hazards in the coastal area

$2, \ldots, n)$ those respond to such security aspects $\mathrm{j}$ in the following equation:

$\mathrm{SI}_{\mathbf{j}}=\left\{\sum_{\mathbf{i}=1}^{\mathbf{n}} \mathrm{X}_{\mathrm{ij}} / \mathrm{M}_{\mathrm{j}}\right\} \times 100$

where, $\mathrm{SI}_{\mathrm{j}}$ is the Security level under $\mathrm{jth}$ individual aspect, $\mathrm{X}_{\mathrm{ij}}$ is the Positive score of ith indicators under jth aspect.

The value of $\mathrm{X}$ for the different indicators $(\mathrm{i}=1$ to $\mathrm{n}$ ) has been calculated by counting the numbers of positive $(+)$ signs. $\mathrm{n}$ is the Number of individual indicators sensitive for individual aspect, $M_{j}$ is the Total score of responsive indicators under $\mathrm{jth}$ aspect, $\mathrm{j}$ is the Different security aspects $(1-5)$

Now the overall livelihood security at the household level of a coastal community against the hazard (stormsurge) can be calculated through combining the security scores under all denoted security aspects. The composite Security Index consisting of different aspects has been expressed as follows:

$$
\mathbf{S I}=\sum_{\mathbf{j}=1}^{\mathbf{N}} \mathbf{S} \mathbf{I}_{\mathbf{j}} / \mathbf{N}
$$

where, SI level of livelihood security for household (in percentage), $N$ number of security aspects considered in the composite index.

\section{Model application}

The assessment of security level may have to deal with multiple sources of uncertainty that the model can consider automatically as per its analytical approach. In this model, uncertainty factors are directly related to the the stormsurge charecteristics: its action, scope of defenses etc. and also human behavior. It may also have to deal with the ecosystem conservation knowledge as well as institutional capacity. All those factors and their relevance were studied and justified using expert's opinion in indicator development process. Therefore, we are confident that the indicator 
Table 2 Primarily identified security indicators for livelihoods in the coastal community

\begin{tabular}{|c|c|c|c|}
\hline Resources & Indicator & Unit & Standard/threshold value \\
\hline \multirow[t]{10}{*}{ Natural resources } & Frequency of storm-surges (normal/frequent) & Binary & 1 \\
\hline & Storm-surge period (normal/high tide) & Binary & 1 \\
\hline & Surge height from mean sea level (normal/high) & Binary & 1 \\
\hline & Duration of surge (regular/long term) & Binary & 1 \\
\hline & Rate of vegetation around the area & $\%$ & 25 \\
\hline & Time frame for resource collection or production & Month & 12 \\
\hline & Performance of natural drainage system & $\%$ & 80 \\
\hline & Rate of possible resource quality improvement & $\%$ & 50 \\
\hline & Access to alternative resource base & No. & 3 \\
\hline & Available energy/fuel supply & $\%$ & 90 \\
\hline \multirow[t]{9}{*}{ Financial Resources } & Homestead production & $\%$ of $\mathrm{TI}$ & 40 \\
\hline & Ownership on main production or income & $\%$ & 75 \\
\hline & Scope of food storage (Yes/No) & Binary & 1 \\
\hline & Rate of saving & $\%$ of $\mathrm{TI}$ & 25 \\
\hline & Reliability of saving system & Binary & 1 \\
\hline & Access of women to economic activities & $\%$ & 50 \\
\hline & Scope of alternative economic activities (Yes/No) & Binary & 1 \\
\hline & Access to financial loan (Yes/No) & Binary & 1 \\
\hline & Portion of $\mathrm{HH}$ income earned from rest of the country & $\%$ & 20 \\
\hline \multirow[t]{10}{*}{ Human Resources } & Rate of education/literacy & $\%$ & 80 \\
\hline & Knowledge on first aid & $\%$ & 70 \\
\hline & Knowledge on storm-surge risks & $\%$ & 80 \\
\hline & Access to nearest district town (Yes/No) & Binary & 1 \\
\hline & Access to medical services (No. of doctor/50 HHs) & No. & 2 \\
\hline & $\mathrm{HH}$ population having training on surge protection & $\%$ & 50 \\
\hline & Active population of $\mathrm{HHs}$ & $\%$ & 50 \\
\hline & Response to early warning system & $\%$ & 65 \\
\hline & Rate of out migration of $\mathrm{HH}$ members & $\%$ & 10 \\
\hline & Response to adaptation technology & $\%$ & 75 \\
\hline \multirow[t]{10}{*}{ Physical Resources } & Safe housing infrastructure/condition & $\%$ & 60 \\
\hline & Performance of hospital/health centers & Scale & 3 \\
\hline & Performance of/access to cyclone shelters & $\%$ & 90 \\
\hline & Availability of drinking water (safe water) & $\%$ & 90 \\
\hline & Sanitation facilities & $\%$ & 90 \\
\hline & Access of Radio/TV/Cell phone & $\%$ & 75 \\
\hline & Availability of paved road & $\%$ & 60 \\
\hline & Transportation facilities & $\%$ & 60 \\
\hline & Part of area under protection structure & $\%$ & 80 \\
\hline & Fitness of protection structure & $\%$ & 80 \\
\hline \multirow[t]{9}{*}{ Social resources } & Performance of weather forecasting & Scale & 3 \\
\hline & Community participation practice & $\%$ & 80 \\
\hline & Activeness of local GOs & Scale & 2 \\
\hline & Inter-relationship with NGOs & Scale & 2 \\
\hline & Performance of social law and regulations & Scale & 2 \\
\hline & Political influence on social group/committee (Yes/No) & Binary & 1 \\
\hline & Performance of local disaster management committee & Scale & 2 \\
\hline & Activeness of social organization of livelihood groups & $\%$ & 80 \\
\hline & Awareness program on protection measures (No/Yes) & No. & 2 \\
\hline
\end{tabular}

(Source BBS, NWRD and Field study 2008-2009, 2011-2013) 
Table 3 Indicator parameters and symbols used in the model

\begin{tabular}{lll}
\hline Parameters & Unit & Denoted by \\
\hline $\begin{array}{l}\text { Measured/present value of } \\
\text { individual indicator }\end{array}$ & Specific unit & $\mathrm{I}_{\mathrm{p}}$ \\
$\begin{array}{l}\text { Standard value of individual } \\
\text { indicator }\end{array}$ & Specific unit & $\mathrm{I}_{\mathrm{s}}$ \\
$\begin{array}{l}\text { Difference between the } \\
\text { present value of indicator } \\
\text { and standard value of } \\
\text { individual indicator }\end{array}$ & $\%$ & $\mathrm{I}_{\mathrm{d}}$ \\
\hline
\end{tabular}

selection and scoring procedure will work sufficiently to identify and resolve such uncertainty. We applied the livelihood security model against storm-surge hazards in two selected areas; a high storm-surge risk area in Cox's Bazar and a medium storm-surge risk area in Satkhira (PDO-ICZMP 2004).

\subsection{Assessment of livelihood security indicators}

We used the indicators for constructing a model for both qualitative and quantitative requirements. The indicator values have been analyzed under specific units or scales such as percentage, number, degree and binary options (shown in the Table 2). Some values have been calculated from the relevant data-base and some have been defined from direct household interview in the study areas. Appendix Tables 8 and 9 shows the present measured value of indicators (Ip) for different livelihood groups in the study areas (a) the Cox's Bazar and (b) Satkhira. During evaluation of indicators from data analysis (results shown in Appendix Tables 8 and 9), we found two major categories: 1) common/same values for livelihood groups and 2) different values for individual group in each area. The first type of indicator shows the collective security status that means the same value for overall community households in the defined area and the second type actually indicates the value especified as individual household basis for different groups. For example, the indicator "performance of hospital/health center" shows the same measured unit value for all livelihood groups living in the same area where the "Rate of production" shows different value for different groups in such area.

\subsection{Security scoring for individual indicators}

We used AHP methods to make the decision for priority of indicators under the security options, and these can then be taken up in quantitative surveys. The priority-scored indicators have been used for measuring security level under individual security options such as food security, income security and so on for each livelihood group. Priority selection is shown in Appendix Table 10. The security score under individual indicators has been estimated from the comparative analysis between present field survey data $\left(\mathrm{I}_{\mathrm{p}}\right.$ ) (Appendix Tables 8 and 9) and standard threshold values $\left(I_{S}\right)$ (Table 2) according to national average value (from BBS year books, NWRD and Local Government Organizations) by using Eq. 1 described in Sect. 4.2. From the difference of individual indicator's values the security scores have been found under different security options. For better understanding of security scoring process, we used a sample calculation where we used the limited number of indicators $(n=5)$ with only 2 security options for one livelihood group.

Table 5 shows a sample input data calculation for the livelihood security measurement of farmer households in Cox's Bazar applying steps 1 and 2 of the model described in Sect. 4.2. Here, in the second row of the Table 5, individual indicator $\mathrm{i}=1$ was selected under the food security (j1) aspect for the farmer group in Cox's Bazar. The present value of i1 is 0 where the security standard (defined in Table 2$)$ is 1 . Now the value difference $\left(I_{q}\right)$ is about $100 \%$ with negative direction that means i1 shows insecurity in food with score 3 according to the security scale defined in Table 4 . In the same process, $i=2$ and $i=3$ were investigated where $i=2$ was not responding for food security according to the AHP analysis (Appendix Table 10). So, i2 is not scored under food security, however it scored 1 for income security (j2) in the negative direction $\mathrm{i} 3$ is scored for both security options as 1 in the negative direction. However, $\mathrm{i}=4$ and $\mathrm{i}=5$ indicators have shown in scores 1 and 2, respectively food security and income security was relatively in the positive direction. Here, the calculated score under food security aspect/option $(j=1)$ is 3 , whereas the total score is $7\left(M_{1}=7\right)$. So, in the model, $\sum \mathrm{X}_{1}=3$.
Table 4 Scale for security scoring in individual indicators

\begin{tabular}{lllll}
\hline Positive $I_{d}=$ Security & & & Negative $I_{d}=$ Insecurity & \\
\cline { 5 - 5 } Security score $(X)$ & $(+)$ Value range $(\%)$ & & Insecurity score $(Y)$ & $(-)$ Value range $(\%)$ \\
\hline+ & $0-30$ & - & $0-30$ \\
++ & $31-60$ & -- & $31-60$ \\
+++ & $61->$ & --- & $61->$ \\
\hline
\end{tabular}

Here, $X$ security score for individual indicator, $Y$ insecurity score for individual indicator 
Table 5 Calculation for security scoring of five indicators (farmers in Cox's Bazar area)

\begin{tabular}{|c|c|c|c|c|c|c|c|c|}
\hline SL & Indicators (i) & Unit & $\mathrm{I}_{\mathrm{s}}$ & $\mathrm{I}_{\mathrm{p}}$ & $\mathrm{I}_{\mathrm{d}}(\%)$ & Direction & $\begin{array}{l}\text { Food } \\
\text { security }(j=1)\end{array}$ & $\begin{array}{l}\text { Income } \\
\text { security }(j=2)\end{array}$ \\
\hline 1 & Duration of storm-surge (short term/long term) & Binary & 1 & 0 & 100.00 & Negative & --- & --- \\
\hline 2 & Rate of vegetation around the area & $\%$ & 25 & 15 & 25.00 & Negative & $\mathrm{x}$ & - \\
\hline 3 & Time frame for resource collection/production & Months & 12 & 8 & 20.00 & Negative & - & - \\
\hline 4 & Rate of possible resource quality improvement & $\%$ & 50 & 60 & 9.09 & Positive & + & + \\
\hline 5 & $\begin{array}{l}\text { Access to alternative resource base } \\
\sum \mathbf{X}\end{array}$ & No. & 3 & 6 & 33.33 & Positive & $\begin{array}{l}++ \\
3 \\
7\end{array}$ & $\begin{array}{l}++ \\
3 \\
8\end{array}$ \\
\hline
\end{tabular}

(Source Model results 2011; 2013)

\subsection{Calculation of security level for individual security options}

The levels of different security options have been measured by using Eq. 2 under Step 3.

$$
\begin{aligned}
& \mathrm{SI}_{1}=\left(\sum \mathrm{X}_{1} / \mathrm{M}_{1}\right) \times 100=(3 / 7) \times 100 \\
& \mathrm{j}=1, \text { defines food security } \\
& \quad=42.86 \%
\end{aligned}
$$

Therefore, the calcutated food security for the sample indicators is $42.86 \%$ (sample calculation partially using only 5 indicators, it is not the complete scenario). Tables 6 and 7 show the complete measured value of security (as a percentage) under the individual security option $\left(\mathrm{SI}_{\mathrm{j}}\right)$ for the selected livelihood groups in the study areas.

In Table 6, security levels under individual options have been presented for the defined livelihood groups in Cox's Bazar area. These results were measured by using Eq. 2 of the model. The same process was followed in Satkhira area; the results are shown in Table 7. The values shown in Tables 6 and 7 are the input data for Eq. 3 of the model.

\subsection{Calculation of security level of livelihood groups}

The overall security level of the coastal livelihood groups were calculated using Eq. 3 in the third step of the

\begin{tabular}{|c|c|c|c|c|c|c|}
\hline Security options (j) & Farmer & Fisherman & Wage labourer & Fry collector & Dry fisher & Salt farmer \\
\hline Food security $\mathbf{S I}_{\mathbf{1}}$ & 41.67 & 41.18 & 19.35 & 16.13 & 40.82 & 45.83 \\
\hline Income security $\mathbf{S I}_{2}$ & 44.68 & 42.86 & 23.08 & 17.86 & 39.58 & 47.92 \\
\hline Health and personal security $\mathbf{S I}_{\mathbf{3}}$ & 38.30 & 37.25 & 13.79 & 11.48 & 35.42 & 42.55 \\
\hline Security of house and properties $\mathbf{S I}_{\mathbf{4}}$ & 45.65 & 42.86 & 18.87 & 15.79 & 40.43 & 48.94 \\
\hline Water security $\mathbf{S I}_{\mathbf{5}}$ & 39.13 & 35.29 & 14.29 & 13.56 & 34.69 & 40.43 \\
\hline
\end{tabular}
Livelihood Security Model. For example, in theCox'sBazar

Table 6 Individual security level (\%) for livelihood groups in Cox's Bazar area

\begin{tabular}{|c|c|c|c|c|c|}
\hline Security options (j) & Farmer & Fisherman & Wage labourer & Fry collector & Forest extractor \\
\hline Food security $\mathbf{S I}_{\mathbf{1}}$ & 34.00 & 27.27 & 13.43 & 17.54 & 26.92 \\
\hline Income security $\mathbf{S I}_{2}$ & 37.25 & 28.30 & 16.39 & 18.18 & 25.93 \\
\hline Health and personal security $\mathbf{S I}_{\mathbf{3}}$ & 30.77 & 18.18 & 6.15 & 12.73 & 22.41 \\
\hline Security of house and properties $\mathbf{S I}_{\mathbf{4}}$ & 36.54 & 26.92 & 13.11 & 18.52 & 29.09 \\
\hline Water security $\mathbf{S I}_{5}$ & 31.37 & 20.00 & 8.06 & 13.73 & 21.43 \\
\hline
\end{tabular}

(Source Model results 2011; 2013)

Table 7 Individual security level (\%) for livelihood groups in Satkhira area

(Source Model results 2011; 2013) 


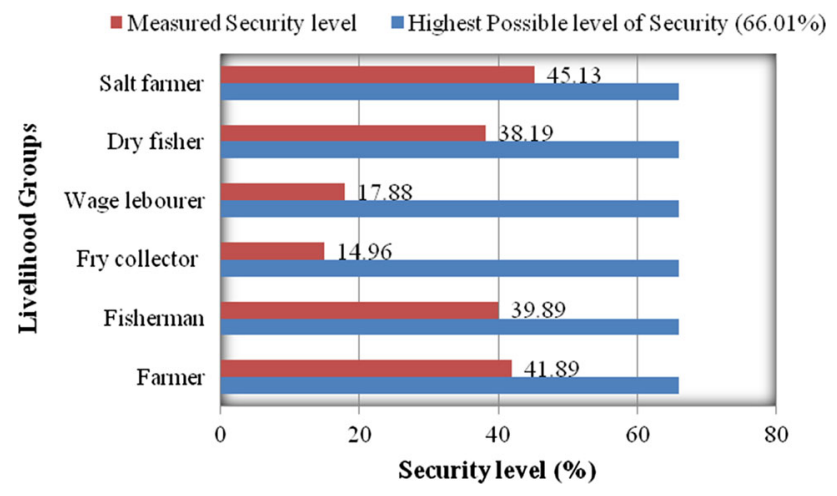

Fig. 4 Computation of security level at Cox's Bazar for the period of 2013 (Source Mutahara and Haque 2011; Mutahara et al. 2013)

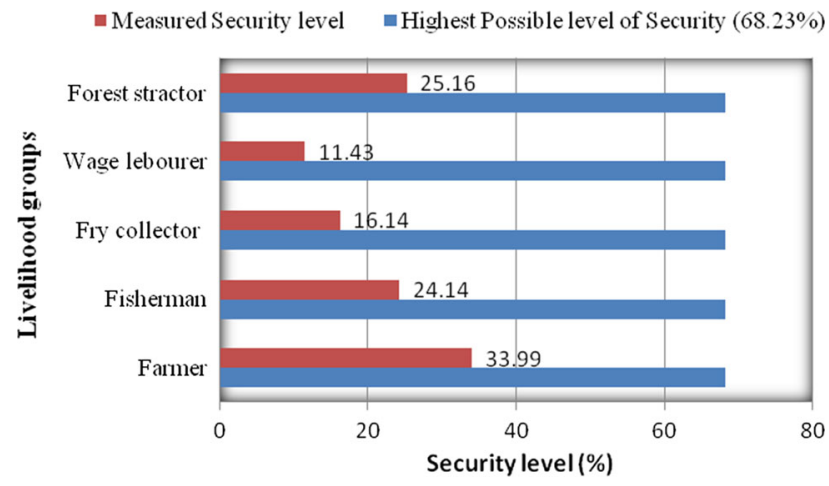

Fig. 5 Computation of security level at Satkhira area for the period of 2013 (Source Mutahara and Haque 2011; Mutahara et al. 2013)

area, the security level of the farmer group is calculater as follows:

$$
\begin{aligned}
\mathrm{SI}_{\mathrm{Farmer}} & =\left(\mathrm{SI}_{1}+\mathrm{SI}_{2}+\mathrm{SI}_{3}+\mathrm{SI}_{4}+\mathrm{SI}_{5}\right)_{\mathrm{Farmer}} / 5 \\
& =(41.67+44.68+38.30+45.65+39.13) / 5 \\
& =41.89(\%)
\end{aligned}
$$

Figures 4 and 5 show the overall model results.

\section{Results and discussion}

Figures 4 and 5 present the model results for Cox's Bazar and Satkhira areas, respectively. In both areas, the results have determined the livelihood security of individual groups. The lowest security level $14.96 \%$ was found for fry collectors (Fig. 4). In the Cox'sBazar area, the fry collectors live at a very marginal level, with access to but not ownership of marine resources. Women and children are mostly involved in fry collection using very traditional instruments. In most cases they lost their instruments and cannot go to sea during and also long time after a stormsurge. Wage labourer group is also less secure (17.88 \%) because of limited scope of work during and after a stormsurge. However, they have some access to rehabilitation work with other groups like agriculture, salt farmer or dry fisher. On the other hand, the highest security was found for salt farmer group in Cox's Bazar. They have ownership to land which they use for salt farming. They have seasonal investment and income. We found that farmers can preserve the produced salt in the field giving mud cover during the occurence of a storm-surge. Farmer, fisherman and dry fisher groups were also at relatively higher security levels.

The models result from Satkhira area is shown in Fig. 5. In Satkhira the wage labour group was found as the least secure livelihood group. This area is highly dependent on culture fisheries (shrimp culture). The labourers mainly work in the shrimp field on a daily basis. Therefore, they do not have independent access to income generation. Fry collectors are also in a less secure zone. The highest security level (33.99 \%) was found for farmers in Satkhira. In this coastal area farmers cultivate rice and vegetables. Currently they use high yielding varities of rice. Crop rotation also make them secure against the loss from storm surges. The forest extractors were also found to have a relatively higher security level because of their seasonal income opportunity. However they are still vulnerable in their dependancy on forest resources only.

In Figs. 4 and 5, the standard household security level has also been determined. The standard level is used for the justification of model application. The standard method of model validation could not be followed properly for the model in such a very rural coastal area. With this limitation, we checked the model with a pre-defined standard security (degree of safety) level for households in each coastal district, as perceived by the community. In both areas(Cox's Bazar and Satkhira), the local communities responded positively to the defined possible standard security level as they expected. The standard livelihood security value is about $66.01 \%$ in the Cox's Bazar area. Following the same methodology, the standard level of security value may be as high as $68.23 \%$ in Satkhira. Figures 4 and 5 shown that marginal livelihood groups have very low levels of livelihood security. Even the security levels of the livelihood groups having the highest security levels, e.g. salt farmers in Cox's Bazar (45.13 \%) and farmers in Satkhira (33.99 \%), are low compared to the standard level of security.

The model results indicate another important finding. We can easily draw a comparative assessment among the commom livelihood groups in different cases. In this study, we found four common groups (farmer, fisherman, fry collector, and wage labourers) in two study areas. Figure 6 shows the variation in household security level among theses common livelihood groups in Cox's Bazar and Satkhira. 


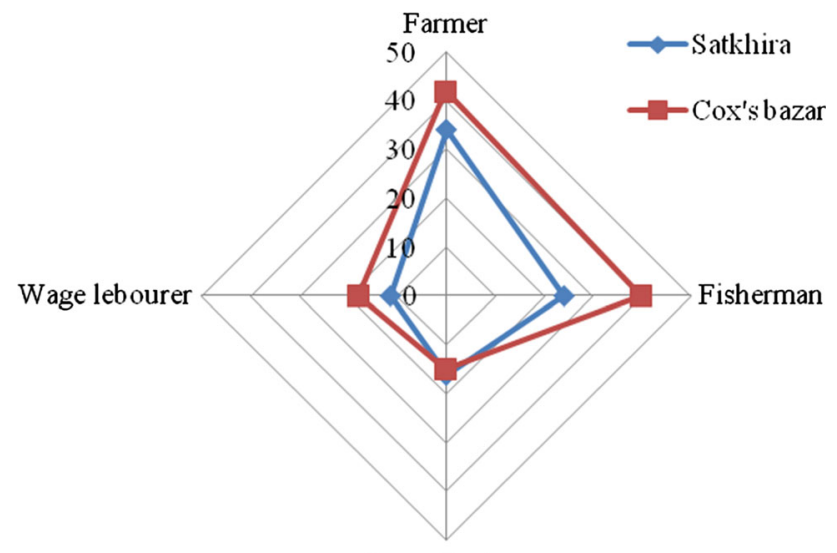

Fry collector

Fig. 6 Comparative analysis of livelihood security in two study sites (Mutahara et al. 2013)

In our findings, the major difference is shown in the fisherman group. The fisherman group in Cox's Bazar (39.89 \%) is more secure than in Satkhira (24.14\%). This is likely due to the long open seashore in Cox's Bazar and fishermen have more finiancial and logistical support in Cox's Bazar (Mutahara et al. 2013). The level of security for farmers in Cox's Bazar is $41.89 \%$ whereas in Satkhira it is $33.99 \%$. The farmers in Cox's Bazar are more secure than in Satkhira due to land use pattern. In Sathkhira, farmers generally cultivate rice in shrimp fields during the dry season. However, in Cox's Bazar, we found separate fields for shrimp and rice production. The level of security of fry collectors is better in Satkhira $(16.14 \%)$ than in Cox's Bazar (14.96 \%). The fry collectors mainly access the rives and khals (tidal channels) in Satkhira whereas in Cox's Bazar they mostly use the open sea.

\section{Conclusion}

In this study, seven (7) marginal livelihood groups have been identified including their specific livelihood opportunities and resources in two study areas (Cox's Bazar and Satkhira) in Bangladesh. In specific, six (6) groups were living in Cox's Bazar area and five (5) were in Satkhira.
However, four (4) livelihood groups (farmer, fisherman, fry collector, and wage labourer) were common in both sites.

Livelihood security is an impotrant issue in the stromsurge affected areas of the Bangladesh coast. It is not only due to physiographic and socio-economic conditions but also due to climate change vulnerability. In our study, the livelihood security model has two main outcomes. First, it introduced a holistic analytical approach for assessing livelihood security levels. Second, it contributed a tool of livelihood protection and system development for the coastal area. The livelihood Security Index (SI) calculated the overall household security level (in \%) for livelihood groups against the risk of storm surges. The model result shows the livelihood security levels for the marginal livelihood groups in both coastal areas. It also shows a comparative view of livelihood security in common livelihood groups in the different coastal area of Bangladesh.

This study can contribute to future coastal resource management and livelihood development programs. It could play a vital role in the sustainable planning for disaster risk reduction and adaptation management in the Bangladesh coast. Although this model has been developed and applied in the Bangladesh delta, it can also be applied in the coastal zones of other deltas for developing sustainable coastal zone management planning.

Acknowledgments This work was supported by the Netherlands Organization of Scientific Research under Grant W.01.65.339.00. The views and interpretations in this publication are those of the authors and they are not necessarily attributable to their organizations.

Open Access This article is distributed under the terms of the Creative Commons Attribution 4.0 International License (http://crea tivecommons.org/licenses/by/4.0/), which permits unrestricted use, distribution, and reproduction in any medium, provided you give appropriate credit to the original author(s) and the source, provide a link to the Creative Commons license, and indicate if changes were made.

\section{Appendix}

See Tables 8, 9 and 10.

Table 8 Input data for livelihood groups in Cox's Bazar area

\begin{tabular}{|c|c|c|c|c|c|c|}
\hline Indicators & Farmers & $\begin{array}{l}\text { Fisher- } \\
\text { man }\end{array}$ & $\begin{array}{l}\text { Fry } \\
\text { collectors }\end{array}$ & $\begin{array}{l}\text { Salt } \\
\text { farmers }\end{array}$ & $\begin{array}{l}\text { Dry } \\
\text { fishers }\end{array}$ & $\begin{array}{l}\text { Wage } \\
\text { labourers }\end{array}$ \\
\hline Frequency of storm-surge (Irregular/regular) & 0 & 0 & 0 & 0 & 0 & 0 \\
\hline Storm surge period (low tide/high tide) & 0 & 0 & 0 & 0 & 0 & 0 \\
\hline Surge height from the main sea level & 0 & 0 & 0 & 0 & 0 & 0 \\
\hline Duration of storm surge (short/long term) & 0 & 0 & 0 & 0 & 0 & 0 \\
\hline Rate of vegetation around the area & 15 & 15 & 15 & 15 & 15 & 15 \\
\hline Time frame for resource collection/production & 8 & 10 & 7 & 6 & 6 & 12 \\
\hline
\end{tabular}


Table 8 continued

\begin{tabular}{|c|c|c|c|c|c|c|}
\hline Indicators & Farmers & $\begin{array}{l}\text { Fisher- } \\
\text { man }\end{array}$ & $\begin{array}{l}\text { Fry } \\
\text { collectors }\end{array}$ & $\begin{array}{l}\text { Salt } \\
\text { farmers }\end{array}$ & $\begin{array}{l}\text { Dry } \\
\text { fishers }\end{array}$ & $\begin{array}{l}\text { Wage } \\
\text { labourers }\end{array}$ \\
\hline Performance of natural drainage system & 55 & 55 & 55 & 55 & 55 & 55 \\
\hline Possible improvement of resource in each year & 60 & 80 & 75 & 75 & 80 & 50 \\
\hline Access to alternative resource base & 6 & 6 & 5 & 4 & 5 & 2 \\
\hline Access to energy/fuel supply & 70 & 50 & 60 & 60 & 60 & 60 \\
\hline Household production & 40 & 12 & 15 & 45 & 30 & 10 \\
\hline Ownership on production & 75 & 50 & 60 & 60 & 60 & 18 \\
\hline Scope of food storage & 1 & 1 & 0 & 1 & 1 & 0 \\
\hline Rate of saving & 25 & 30 & 6.67 & 20 & 16.67 & 0 \\
\hline Reliability of saving system (Yes/No) & 1 & 1 & 0 & 1 & 1 & 0 \\
\hline Access of women to economic activities & 60 & 40 & 75 & 30 & 65 & 45 \\
\hline Scope of alternative economic activities & 1 & 1 & 1 & 1 & 1 & 1 \\
\hline Access to financial loan & 1 & 1 & 0 & 1 & 1 & 0 \\
\hline Portion of $\mathrm{HH}$ income & 15 & 12 & 6 & 32 & 19 & 3 \\
\hline Rate of education/literacy & 52 & 46 & 34 & 44 & 52 & 25 \\
\hline Knowledge on first aid & 46.22 & 30 & 31 & 43 & 22 & 18 \\
\hline Knowledge on storm surge risk & 66.9 & 82 & 66 & 80 & 67.97 & 43 \\
\hline Access to nearest district town $(\mathrm{Yes} / \mathrm{No})$ & 1 & 1 & 1 & 1 & 1 & 1 \\
\hline Access to doctor service (doctor/100 HHs) & 2 & 2 & 2 & 2 & 2 & 2 \\
\hline $\mathrm{HH}$ population having training on surge protection & 30 & 43 & 17 & 47 & 41 & 7 \\
\hline Active population of $\mathrm{HH}$ & 52 & 46 & 34 & 44 & 52 & 25 \\
\hline Response to early warning system & 63 & 67 & 48 & 65 & 68 & 50 \\
\hline Response to adaptation technology & 75 & 76 & 54 & 80 & 77 & 38 \\
\hline Rate of out migration of $\mathrm{HH}$ member & 10 & 11 & 6 & 12 & 9 & 3 \\
\hline Safe housing infrastructure/condition & 40 & 39 & 31 & 62 & 41 & 14.89 \\
\hline Performance of hospital/health center & 2 & 2 & 2 & 2 & 2 & 2 \\
\hline Performance of/access to cyclone shelter & 70 & 70 & 70 & 70 & 70 & 60 \\
\hline Availability of drinking water (safe water) & 45 & 48 & 26 & 56 & 41 & 35 \\
\hline Sanitation facilities & 55 & 61 & 26 & 67 & 38 & 35 \\
\hline Access of media connection/Radio/TV/Cell phone & 80 & 65 & 48 & 75 & 56 & 38 \\
\hline Availability of paved road & 60 & 60 & 60 & 60 & 60 & 60 \\
\hline Transportation facilities & 60 & 60 & 60 & 60 & 60 & 60 \\
\hline Part of area under protection structure & 50 & 50 & 50 & 50 & 50 & 50 \\
\hline Fitness of protection structure & 60 & 60 & 60 & 60 & 60 & 60 \\
\hline Performance of weather forecasting & 2 & 2 & 2 & 2 & 2 & 1 \\
\hline Community participation practice & 75 & 80 & 65 & 85 & 80 & 40 \\
\hline Activeness of local GOs & 2 & 65 & 40 & 62 & 60 & 30 \\
\hline Interrelationship with NGOs & 2 & 75 & 88 & 55 & 70 & 80 \\
\hline Performance social law and regulation & 2 & 2 & 1 & 3 & 3 & 1 \\
\hline Political influence on social group/committee (Yes/No) & 1 & 1 & 0 & 1 & 1 & 0 \\
\hline Performance of local disaster management committee & 2 & 2 & 2 & 2 & 2 & 2 \\
\hline Activeness of social organization of livelihood groups & 60 & 80 & 50 & 85 & 80 & 45 \\
\hline Awareness program on protection measure (No/Yes) & 2 & 2 & 2 & 2 & 2 & 2 \\
\hline
\end{tabular}

(Source Survey 2010-2011) 
Table 9 Input data for livelihood groups in Satkhira area

\begin{tabular}{|c|c|c|c|c|c|}
\hline Indicators & Farmers & Fisherman & Fry collectors & Forest extractors & Wage labourers \\
\hline Frequency of storm surge (Irregular/regular) & 0 & 0 & 0 & 0 & 0 \\
\hline Storm surge period (Low tide/high tide) & 0 & 0 & 0 & 0 & 0 \\
\hline Surge height from main sea level & 0 & 0 & 0 & 0 & 0 \\
\hline Duration of storm surge (Short term/long term) & 0 & 0 & 0 & 0 & 0 \\
\hline Rate of vegetation around the area & 18 & 18 & 18 & 18 & 18 \\
\hline Time frame for resource collection/production & 8 & 10 & 7 & 8 & 12 \\
\hline Performance of natural drainage system & 40 & 40 & 40 & 40 & 40 \\
\hline Possible improvement of resource in each year & 60 & 80 & 75 & 30 & 50 \\
\hline Access to alternative resource base & 6 & 6 & 5 & 4 & 2 \\
\hline Access to energy/fuel supply & 45 & 25 & 25 & 25 & 25 \\
\hline Household production & 40 & 12 & 15 & 40 & 10 \\
\hline Ownership on production & 70 & 70 & 60 & 60 & 20 \\
\hline Scope of food storage & 0 & 0 & 0 & 1 & 0 \\
\hline Rate of saving & 20 & 10 & 5.33 & 25 & 0 \\
\hline Reliability of saving system (Yes/No) & 1 & 0 & 0 & 1 & 0 \\
\hline Access of women to economic activities & 50 & 30 & 66 & 20 & 55 \\
\hline Scope of alternative economic activities & 1 & 1 & 1 & 1 & 1 \\
\hline Access to financial loan & 1 & 1 & 1 & 1 & 0 \\
\hline Portion of HHs income earned from rest of the country & 18.65 & 6 & 2.75 & 9.68 & 5 \\
\hline Rate of education/literacy & 48 & 39 & 31 & 35 & 18 \\
\hline Knowledge on first aid & 29.1 & 12 & 36 & 47 & 20 \\
\hline Knowledge on storm surge risk & 52 & 63 & 65 & 72 & 46 \\
\hline Access to nearest district town (Yes/No) & 0 & 0 & 0 & 0 & 0 \\
\hline Access to doctor service (No. of doctor/100 HHs) & 1 & 1 & 1 & 1 & 1 \\
\hline HH Population having training on Surge protection & 25 & 38 & 18 & 56 & 5 \\
\hline Active population of $\mathrm{HHs}$ & 48 & 39 & 31 & 35 & 18 \\
\hline Response to early warning system & 55 & 65 & 42 & 67 & 47 \\
\hline Response to adaptation technology & 62 & 46 & 47 & 64 & 52 \\
\hline Rate of out migration of $\mathrm{HH}$ members & 8 & 5 & 2.75 & 8 & 1.5 \\
\hline Safe housing infrastructure/condition & 46 & 22 & 22 & 48 & 9 \\
\hline Performance of hospital/health center & 2 & 2 & 2 & 2 & 2 \\
\hline Performance of/access to cyclone shelter & 60 & 60 & 60 & 60 & 70 \\
\hline Availability of drinking water (safe water) & 48 & 28 & 24 & 35 & 33 \\
\hline Sanitation facilities & 48 & 32 & 20 & 38 & 33 \\
\hline Access of media connection/Radio/TV/cell phone & 78 & 35.5 & 30 & 30 & 40 \\
\hline Availability of paved road & 65 & 65 & 65 & 65 & 65 \\
\hline Transportation facilities & 55 & 55 & 55 & 55 & 55 \\
\hline Part of area under protection structure & 35 & 35 & 35 & 35 & 35 \\
\hline Fitness of protection structure & 40 & 40 & 40 & 40 & 40 \\
\hline Performance of weather forecasting & 1 & 1 & 1 & 3 & 1 \\
\hline Community participation practice & 65 & 60 & 50 & 60 & 40 \\
\hline Activeness of local GO & 1 & 40 & 35 & 45 & 30 \\
\hline Interrelationship with NGO & 2 & 80 & 90 & 65 & 80 \\
\hline Performance social law and regulation & 1 & 1 & 1 & 3 & 1 \\
\hline Political influence on social group/committee(Yes/No) & 1 & 1 & 0 & 1 & 0 \\
\hline Performance of local disaster management committee & 1 & 1 & 1 & 1 & 1 \\
\hline Activeness of social organization of livelihood groups & 50 & 60 & 55 & 70 & 50 \\
\hline Awareness program on protection measure $(\mathrm{No} / \mathrm{Yes})$ & 0 & 0 & 0 & 0 & 0 \\
\hline
\end{tabular}

(Source Survey 2010-2011) 
Table 10 Priority calculation under different security options (selected indicators by AHP)

\begin{tabular}{|c|c|c|c|c|c|c|}
\hline \multirow[t]{2}{*}{ Resources } & \multirow[t]{2}{*}{ Indicator } & \multicolumn{5}{|c|}{ Priority/response to different security options } \\
\hline & & Food & Income & $\begin{array}{l}\text { Health and } \\
\text { personal }\end{array}$ & $\begin{array}{l}\text { House and } \\
\text { properties }\end{array}$ & Water \\
\hline \multirow[t]{10}{*}{ Natural resources } & Frequency of storm surge (Irregular/regular) & 0.02 & 0.01 & 0.01 & 0.01 & 0.04 \\
\hline & Storm surge period (Low tide/high tide) & 0.02 & 0.01 & 0.01 & 0.01 & 0.03 \\
\hline & Surge height from mean sea level & 0.02 & 0.01 & 0.01 & 0.01 & 0.03 \\
\hline & Duration of storm surge (Short term/long term) & 0.02 & 0.01 & 0.01 & 0.01 & 0.02 \\
\hline & Rate of vegetation around the area & 0.00 & 0.01 & 0.01 & 0.04 & 0.01 \\
\hline & Time frame for resource collection/production & 0.05 & 0.04 & 0.00 & 0.00 & 0.00 \\
\hline & Performance of natural drainage system & 0.00 & 0.00 & 0.01 & 0.04 & 0.08 \\
\hline & Rate of possible resource quality improvement & 0.08 & 0.02 & 0.00 & 0.00 & 0.00 \\
\hline & Access to alternative resource base & 0.05 & 0.03 & 0.02 & 0.02 & 0.02 \\
\hline & Access to energy/fuel supply & 0.04 & 0.01 & 0.02 & 0.00 & 0.05 \\
\hline \multirow[t]{9}{*}{ Financial resources } & Homestead production & 0.08 & 0.03 & 0.01 & 0.02 & 0.02 \\
\hline & Ownership on main production or income & 0.05 & 0.04 & 0.02 & 0.03 & 0.09 \\
\hline & Scope of food storage (Yes/No) & 0.04 & 0.00 & 0.02 & 0.00 & 0.00 \\
\hline & Rate of saving & 0.04 & 0.01 & 0.02 & 0.03 & 0.06 \\
\hline & Reliability of saving system & 0.03 & 0.02 & 0.01 & 0.02 & 0.05 \\
\hline & Access of women to economic activities & 0.02 & 0.02 & 0.00 & 0.02 & 0.04 \\
\hline & Scope of alternative economic activities (Yes/No) & 0.02 & 0.01 & 0.00 & 0.01 & 0.00 \\
\hline & Access to financial loan (Yes/No) & 0.01 & 0.01 & 0.01 & 0.01 & 0.03 \\
\hline & Portion of HHs income earned from rest of the country & 0.01 & 0.01 & 0.00 & 0.01 & 0.00 \\
\hline \multirow[t]{10}{*}{ Human resources } & Rate of education/literacy & 0.02 & 0.03 & 0.01 & 0.03 & 0.02 \\
\hline & Knowledge on first aid & 0.06 & 0.00 & 0.02 & 0.00 & 0.07 \\
\hline & Knowledge on storm surge risk & 0.06 & 0.02 & 0.01 & 0.02 & 0.02 \\
\hline & Access to nearest district town (Yes/No) & 0.03 & 0.02 & 0.01 & 0.03 & 0.02 \\
\hline & Access to doctor service (No. of doctor/100HHs) & 0.00 & 0.00 & 0.02 & 0.00 & 0.06 \\
\hline & HH Population having training on Surge protection & 0.04 & 0.02 & 0.01 & 0.02 & 0.03 \\
\hline & Active population of $\mathrm{HHs}$ & 0.03 & 0.02 & 0.01 & 0.01 & 0.02 \\
\hline & Response to early warning system & 0.03 & 0.01 & 0.01 & 0.01 & 0.02 \\
\hline & Response to adaptation technology & 0.02 & 0.01 & 0.01 & 0.01 & 0.02 \\
\hline & Rate of out migration of $\mathrm{HH}$ member & 0.00 & 0.01 & 0.00 & 0.01 & 0.00 \\
\hline \multirow[t]{10}{*}{ Physical Resources } & Safe housing infrastructure/condition & 0.11 & 0.04 & 0.03 & 0.04 & 0.09 \\
\hline & Performance of hospital/Health center & 0.00 & 0.00 & 0.01 & 0.00 & 0.04 \\
\hline & Performance of/access to cyclone shelter & 0.05 & 0.03 & 0.01 & 0.03 & 0.04 \\
\hline & Availability of drinking water (safe water) & 0.04 & 0.00 & 0.01 & 0.00 & 0.03 \\
\hline & Sanitation facilities & 0.03 & 0.00 & 0.01 & 0.00 & 0.02 \\
\hline & Access of Radio/TV/Cell phone & 0.00 & 0.02 & 0.01 & 0.02 & 0.04 \\
\hline & Availability of paved road & 0.02 & 0.01 & 0.00 & 0.01 & 0.00 \\
\hline & Transportation facilities & 0.06 & 0.01 & 0.01 & 0.02 & 0.02 \\
\hline & Average area with protection structure & 0.00 & 0.01 & 0.00 & 0.01 & 0.01 \\
\hline & Fitness of protection structure & 0.00 & 0.01 & 0.01 & 0.02 & 0.00 \\
\hline \multirow[t]{9}{*}{ Social resources } & Performance of weather forecasting & 0.10 & 0.00 & 0.03 & 0.03 & 0.04 \\
\hline & Community participation practice & 0.06 & 0.02 & 0.02 & 0.02 & 0.07 \\
\hline & Activeness of local GO & 0.04 & 0.05 & 0.01 & 0.02 & 0.04 \\
\hline & Interrelationship with NGOs & 0.02 & 0.02 & 0.01 & 0.02 & 0.03 \\
\hline & Performance social law and regulations & 0.00 & 0.00 & 0.01 & 0.01 & 0.03 \\
\hline & Political influence on social committee (Yes/No) & 0.02 & 0.02 & 0.00 & 0.01 & 0.00 \\
\hline & Performance of local disaster management committee & 0.03 & 0.01 & 0.01 & 0.01 & 0.02 \\
\hline & Activeness of social organization of livelihood groups & 0.02 & 0.02 & 0.01 & 0.01 & 0.01 \\
\hline & Awareness program on protection measure $(\mathrm{No} / \mathrm{Yes})$ & 0.02 & 0.02 & 0.01 & 0.02 & 0.05 \\
\hline
\end{tabular}




\section{References}

Ahmad M (2003) Coastal Livelihoods an Introductory Analysis, Program Development Office for Integrated Coastal Zone Management (PDO-ICZM), Dhaka, Bangladesh

Ahsan MN, Warner J (2014) The socioeconomic vulnerability index: a pragmatic approach for assessing climate change led risks-A case study in the south-western coastal Bangladesh. In $\mathrm{J}$ of Diaster Risk Reduction 8:32-49

Ali A (1996) Vulnerability of Bangladesh to climate change and sea level rise through tropical cyclones and storm surges. Water Air Soil Pollut 94:171-179

Ali A (1999) Cyclone, Bangla Academy, Dhaka, Bangladesh, 147p (In Bengali)

Bangladesh Bureau of Statistics (2001) Annual Report of Bangladesh Bureau of Statitics (BBS), Ministry of Planning, Dhaka, Bangladesh

Bangladesh Bureau of Statistics (2011) Annual Report of Bangladesh Bureau of Statitics (BBS), Ministry of Planning, Dhaka, Bangladesh

Bangladesh University of Engineering and Tecnology (BUET) (2008) Field Investigation on the Impact of Cyclone SIDR in the Coastal Region of Bangladesh, Dhaka, Bangladesh

Brammer H (1999) Agricultural disaster management in Bangladesh. University Presss Ltd., Dhaka

Center for Environmental and Geografical Information Services (CEGIS) (2007) Investigating the Impact of Relative Sea-Level Rise on Coastal Communities and their Livelihoods in Bangladesh with UK Department for Environment Food and Rural Affairs, 2007, Dhaka, Bangladesh

Chadwick M (2003) Integrated Coastal Zone Management in Bangladesh, Improving Policy-Livelihood Relationships in South Asia, Policy Review Paper 6

Chambers R, Conway G (1992) Sustainable Rural Livelihoods: Practical Concepts for the 21st Century, Institute of Development Studies (IDS) Discussion Paper No. 296. Brighton, UK

Charvet I, Suppasri A, Imamura F (2014) Empirical fragility analysis of building damage caused by the 2011 Great East Japan tsunami in Ishinomaki city using ordinal regression, and influence of key geographical features. Stoch Environ Res Risk Assess 28:1853-1867

Chowdhury A (2002) Disasters: Issues and Responses, Bangladesh Environment, Facing the 21st Century, Society for Environment and Human Development (SEHD), Bangladesh

Edward HA, Frank E (2001) The livelihoods approach and management of small-scale fisheries. Mar Policy 25:377-388

Emanuel K, Sundararajan R, William J (2008) Hurricanes and global warming: results from downscaling IPCC AR4 simulations. J Clim 89:347-367

Evan D, Fraser G, Dougill AJ, Mabee WE, McAlpine MRP (2005) Bottom up and top down: analysis of participatory processes for sustainability indicator identification as a pathway to community empowerment and sustainable environmental management. J Environ Manag 78:114-127

Fleig AK, Tallaksen LM, Hisdal H, Demuth S (2006) A global evaluation of streamflow drought characteristics. Hydrol Earth Syst Sci 10:535-552

Frankenberger TR, McCaston MK (1998) The Household Livelihood Security Concept. CARE, Atlanta

Ganter E (1996) Indigenous participation in coastal management in the Northern territory, Australia: issues and options. Ocean Coastal Manag 33(1-2):193-212

Goodwin P, Wright G (1998) Decision analysis for management judgment, 2nd edn. Wiley, Chichester

Hasegawa K (2008) Features of Super Cyclone SIDR to Hit Bangladesh in Nov., 07 and Measures for Disaster-from Results of JSCE Investigation, Foundation of River \& Watershed Environment Management, Hokkaido Office, Sapporo, Japan
Huq H (2001) People's Participation, Exploring Contestation, Counter-Development and Rural livelihoods, Community Development Library, Dhaka, Bangladesh

Intergovernmental Panel on Climate Change (IPCC) (1996) The Second Assessment Report, Cambridge University Press, Cambridge

Islam MR (2004) Where land meets the sea, A Profile of the Coastal Zone Bangladesh. UPL, Dhaka

Khalequzzaman M (1988) Environmental Hazards in the Coastal Areas of Bangladesh: Geologic Approach. In: 3rd international conference on natural and man-made coastal hazards August 15-20, 1988, Ensenada, Baja California, USA

Levy JK, Hall J (2005) Advanced in flood risk management under uncertainty. Stoch Environ Res Risk Assess 19:375-377

Mutahara M (2009) Development of a Sustainable Livelihood Security Model for Storm Surge Hazard in Coastal Area, Unpublished M.Sc thesis, Institute of Water and Flood Management (IWFM), Bangladesh University of Engineering and Technology, Dhaka

Mutahara M, Haque A (2011) Development of a Sustainable Livelihood Security Model for Storm Surge Hazard in Coastal Area. In: Proceedings of the 3rd International Conference on Water and Flood Management ICWFM-2011, Dhaka, Bangladesh

Mutahara M, Haque A, Wester P (2013) Livelihood System and Challenge of Living in the Coast: A Case Study in Southwest Coastal Area of Bangladesh. In: Proceedings of the 4th International Conference on Water and Flood Management, ICWFM, 2013, Volume 2, Dhaka, Bangladesh

NWRD (2010) National Water Resources databasse, Ministry of water Resources, Dhaka Bangladesh

Program Development Office for Integrated Coastal Zone Management (PDO-ICZM) (2002) Perceptions of Direct Stakeholders on Coastal livelihoods; Working Paper wp004 of the project. Water Resources Planning Organization, Ministry of Water Resources, Dhaka, Bangladesh

Program Development Office for Integrated Coastal Zone Management (PDO-ICZMP) (2003) Coastal Livelihoods; an introductory analysis, Working paper wp011. Water Resources Planning Organization, Ministry of Water Resources, Bangladesh. Dhaka, January 2003

Program Development Office for Integrated Coastal Zone Management (PDO-ICZMP) (2004) Living in the Coast: People and Livelihoods, Living in the Coast Series 1. Water Resources Planning Organization, Ministry of Water Resources, Bangladesh. Dhaka, March 2004

Rahmam R (2004) Formulation of pro-poor water sector strategy, Final Project Report, Institute of Water and Flood Management, Bangladesh University of Engineering and Technology

Saaty TL (1980) The analytic hierarchy process: planning priority setting resource allocation. McGraw-Hill, New York

Saaty TL (1988) What is the analytic hierarchy process?. Springer, Berlin

Sadiq R, Tesfamariam S (2009) Environmnetal decision-making under uncertainty using intuitionistic fuzzy analytic hierarchy process (IF-AHP). Stoch Environ Res Risk Assess 23:75-91

Soussan J, Datta A (2002) Coastal Development and Livelihoods in Bangladesh, Department for International Development (UK), Dhaka

Tesfamariam S, Sadiq R (2006) Risk-based environmental decisionmaking using fuzzy analytic hierarchy process (F-AHP). Stoch Environ Res Risk Assess 21:35-50

Toufique KA, Turton C (2002) Hands not land: how livelihoods are changing in rural Bangladesh. Bangladesh Institute of Social Studies, Dhaka 